\title{
Supplementing diets for broilers that are low in crude protein and amino acids with protease
}

\author{
S. Sarica ${ }^{1 \#}$, S. Yurtseven ${ }^{2} \&$ I. Polat ${ }^{3}$ \\ ${ }^{1}$ Department of Animal Science, Faculty of Agriculture, Tokat Gaziosmanpasa University, Tokat, Turkey \\ ${ }^{2}$ Department of Animal Science, Faculty of Agriculture, Harran University, Urfa, Turkey; \\ ${ }^{3}$ Department of Animal Science, Faculty of Agriculture, Cukurova University, Adana, Turkey.
}

(Submitted 18 February 2020, Accepted 4 July 2020, Published online 20 August 2020)

\author{
Copyright resides with the authors in terms of the Creative Commons Attribution 4.0 South African Licence. \\ See: http://creativecommons.org/licenses/by/4.0/za \\ Conditions of use: The user may copy, distribute, transmit and adapt the work, but must recognise the authors and the South African \\ Journal of Animal Science.
}

\begin{abstract}
The study evaluated supplementation of broiler diets with a protease enzyme. Six hundred Ross 308 female broiler chicks were acquired at one day of age and randomly distributed to three treatments with five replicates of 40 chicks each. The experimental treatements consisted of i) a positive control diet with normal levels of crude protein, digestible lysine and digestible sulphur containing amino acids (PC); ii) a negative diet with reduced levels of crude protein, digestible lysine and digestible sulphur containg amino acids (NC); and iii) the NC diet augmented with Ronozyme ProAct protease at $200 \mathrm{mg} / \mathrm{kg}$ (NC+ENZY). Compared to the other diets, feeding the PC produced the highest final bodyweight (BW), bodyweight gain (BWG), and feed intake (FI) and best feed conversion ratio (FCR) over $0-42$ days. The PC diet also produced the highest hot and cold carcass yields, ileal protein digestibility and improved the serum biochemistry parameters. Relative to the NC, the NC+ENZY diet increased BW, BWG and FI, improved FCR, increased ileal protein digestibility, hot and cold carcass yields, and the crude protein content of meat. However, it decreased serum triglyceride and very low density lipoprotein (VLDL) cholesterol levels and the crude fat content of meat of broilers. As a result, protease supplementation at the level of $200 \mathrm{mg} / \mathrm{kg}$ may not remove the detrimental effects that are caused by a $6 \%$ reduction in crude protein and digestible amino acids on performance, hot and cold carcass yields and ileal digestibility of crude protein of broilers.
\end{abstract}

Keywords: broiler, growth performance, low crude protein diet, meat, nutrient digestibility, protease, serum biochemistry parameters

\#Corresponding author: senay.sarica@gop.edu.tr

\section{Introduction}

Broiler breeding plays an important role in meeting the animal protein requirements of ithe ncreasing human population in the world and in Turkey. In recent years, the goal of the broiler industry has been to obtain faster growth and high-quality meat production in the minimal time (Dosković et al., 2013). For this purpose, broilers should be fed on diets that meet all their nutrient requirements and have high digestibilitiy and biological values (Dosković et al., 2013). One of the most important nutritional requirements for optimum performance of broilers is to ensure adequate dietary crude protein levels. However, some studies have evaluated practices that allow a reduction of dietary crude protein level, since this would not only decrease nitrogen excretion into the environment (Rada et al., 2016; Mohammadigheisar \& Kim, 2018), but reduce diet costs (Dosković et al., 2013; Mohammadigheisar \& Kim, 2018). Feed costs account for about $60 \%-70 \%$ of broiler production (Dosković et al., 2013).

Protein is the second most important and expensive component of poultry diets. Protein in modern broiler production is supplied predominantly from soybean meal (Ndazigaruye et al., 2019). Soybean meal is a protein source feedstuff with highly digestible protein and a balanced amino acid profile. It meets about $80 \%$ of the protein and amino acid requirements of all poultry types at all life stages (Ndazigaruye et al., 2019). But the digestibility of protein of soybean meal must be improved because its nutritional value is generally reduced by the presence of anti-nutritional factors such as trypsin inhibitors, lectins and non-starch polysaccharides (Dessimoni et al., 2019). Moreover, synthesized amounts of protease in the gastrointestinal system could improve protein hydrolysis in the presence of anti-nutritional factors and could be sufficient to optimize protein utilization by increasing the efficiency of amino acid consumption in poultry (Dosković et al., 
2013; Mohammadigheisar \& Kim, 2018). Besides, some soy protein is passed through the gastrointestinal tract without being completely digested (Freitas et al., 2011; Rada et al., 2016) resulting in environmental pollution (Law et al., 2018). The supplementation of synthetic amino acids and exogenous protease enzyme played a positive role in reducing the dietary crude protein level in a lower cost of production without excessive excretion of nitrogen (Mohammadigheisar \& Kim, 2018).

Chickens that are fed the standard levels of dietary protein can synthesize non-essential amino acids from excess essential amino acids. However, this means that fewer essential amino acids are available for non-essential amino acid synthesis when diets with low amino acid are used (Ndazigaruya et al., 2019). In recent years, the use of synthetic amino acids in low crude protein (LP) diets has been studied. But despite supplementation with synthetic amino acids, at excessive levels LP diets still have negative effects on growth performance, nitrogen digestibility, and production costs (Law et al., 2018). For these reasons, research has concentrated on studies in which the protease enzyme is supplemented to LP diets. Supplementation with single exogenous protease increased the apparent amino acid and protein digestibility effectively in broiler diets, especially LP diets (Law et al., 2018). Also, protease supplementation decreased the negative effects of lectins and trypsin inhibitors by increasing amino acid utilization in poultry (Du Plessis \& Van Rensbury, 2014). But the results of studies conducted with protease supplementation are inconsistent because of the diversity of feed ingredients, the types and definitions of protease, and the differences in methodology (Rada et al., 2016; Mohammadigheisar \& Kim, 2018). In recent years, several studies have investigated the effects on performance and nutrient digestibility of protease supplementation to LP diets for broilers (Favero et al., 2009; Fidelis et al., 2010; Angel et al., 2011; Freitas et al., 2011; Rada et al., 2014; Mahmood et al., 2017; Law et al., 2018; Mohammadigheisar \& Kim 2019). However, little research has focused on the effects on growth performance of protease supplementation to diets that are reduced in crude protein and amino acids (Manangi et al., 2009; Rosa et al., 2009; Fru-Nji et al., 2011; Ndazigaruye et al., 2019).

Therefore, the study investigated the effects of protease supplementation at the level of $6 \%$ to diets with reduced crude protein, digestible lysine and digestible total sulphur amino acids on growth performance, nutrient digestibility, nutrient contents of meat and certain serum biochemistry parameters of broilers.

\section{Material and Methods}

The experimental protocols for the management and care of animals were approved by the Local Ethics Committee for Animal Experimentation at the University of Tokat Gaziosmanpasa in Tokat, Turkey (Resolution No. 2009-HADYEK-007). Six hundred one-day-old Ross 308 female broilers that were supplied from a commercial hatchery (Anadolu Ross, Ankara, Turkey) were used in a 42-day trial. The broiler chicks were weighed, wing-banded and distributed randomly to three treatments with five replicates of 40 chicks each. From hatching until six weeks old, the chicks were kept on floor pens bedded with fresh wood shavings as litter. Temperature was kept at $32{ }^{\circ} \mathrm{C}$ for the first week, $28{ }^{\circ} \mathrm{C}$ for the second week and thereafter at $21^{\circ} \mathrm{C}$. A fluorescent lighting schedule of 23 hours light and 1 hour darkness with an average light intensity of 20 lux was used. The diets, in the form of mash, and drinking water were provided ad libitum throughout the experiment.

The ingredients were ground through a 1-mm screen in preparation for chemical analysis. Prior to formulating the diet, these ingredients were analysed for crude protein (CP), ether extract, starch, and total sugar contents (AOAC, 2007). Metabolizable energy (ME) was calculated based on the analysed values of feedstuffs (WPSA, 1989). The contents of digestible lysine and digestible total sulphur amino acids (methionine and cystine) were analysed in Degussa in Turkey (Istanbul, Turkey). All diets were formulated according to phase feeding practices as chickens advanced in age and weight (Ross 308, 2009). The starter period lasted from 0 to 10 days, the grower period from 11 to 28 days and the finisher period from 29 to 42 days.

The experimental diets included PC: a positive control diet with normal crude protein, digestible lysine and digestible sulphur containg amino acids (methionine+cystine); NC: a negative diet, which had $6 \%$ less crude protein, digestible lysine and digestible sulphur containing amino acids; and NC+ENZY: NC supplemented with protease at $200 \mathrm{mg} / \mathrm{kg}$. The ingredients and nutrient composition of the positive and negative control diets are presented in Table 1. 
Table 1 Ingredients and chemical composition (dry matter basis, $\mathrm{g} / \mathrm{kg}$ ) of the positive and negative control diets for rearing broiler chickens

\begin{tabular}{|c|c|c|c|c|c|c|}
\hline \multirow{3}{*}{ Ingredients } & \multicolumn{6}{|c|}{ Days } \\
\hline & \multicolumn{2}{|c|}{$0-10$} & \multicolumn{2}{|c|}{$11-28$} & \multicolumn{2}{|c|}{$29-42$} \\
\hline & $\begin{array}{c}\text { Positive } \\
\text { control } \\
\text { diet }\end{array}$ & $\begin{array}{l}\text { Negative } \\
\text { control diet }\end{array}$ & $\begin{array}{c}\text { Positive } \\
\text { control } \\
\text { diet }\end{array}$ & $\begin{array}{l}\text { Negative } \\
\text { control diet }\end{array}$ & $\begin{array}{l}\text { Positive } \\
\text { control diet }\end{array}$ & $\begin{array}{c}\text { Negative } \\
\text { control } \\
\text { diet }\end{array}$ \\
\hline Corn & 553.75 & 602.50 & 549.23 & 579.10 & 607.40 & 643.20 \\
\hline Soybean meal & 350.0 & 310.0 & 340.0 & 324.5 & 292.7 & 262.6 \\
\hline Fish meal & 20.3 & 24.7 & 16.5 & 3.4 & & \\
\hline Vegetable oil & 35.0 & 25.4 & 57.6 & 54.8 & 60.3 & 54.4 \\
\hline Dicalcium phosphate & 19.4 & 16.5 & 17.2 & 18.9 & 19.4 & 19.4 \\
\hline Limestone & 9.7 & 9.0 & 9.0 & 8.8 & 8.7 & 9.0 \\
\hline Salt & 2.7 & 2.7 & 2.9 & 3.2 & 3.3 & 3.3 \\
\hline Vitamin-trace mineral premix ${ }^{1}$ & 2.5 & 2.5 & 2.5 & 2.5 & 2.5 & 2.5 \\
\hline DI-Methionine & 3.3 & 3.1 & 2.8 & 2.7 & 2.8 & 2.6 \\
\hline L-Lysine & 1.4 & 1.4 & 0.25 & 0.6 & 1.1 & 1.4 \\
\hline L-Threonine & 1.2 & 1.6 & 0.5 & 1.1 & 0.7 & 1.1 \\
\hline Cholin chloride & 0.75 & & 1.52 & & 1.10 & \\
\hline Sodium Bicarbonate & & 0.6 & & 0.4 & & 0.5 \\
\hline \multicolumn{7}{|l|}{ Chemical composition (calculated) } \\
\hline Dry matter & 884.7 & 882.3 & 885.5 & 885.6 & 885.6 & 883.9 \\
\hline Crude protein & 230.4 & 216.3 & 220.7 & 207.1 & 207.1 & 178.5 \\
\hline Metabolizable energy (Kcal/kg) & 3025 & 3025 & 3152 & 3152 & 3201 & 3203 \\
\hline Calcium & 10.0 & 10.0 & 9.0 & 9.0 & 9.0 & 9.0 \\
\hline Available phosporus & 5.0 & 9.0 & 4.5 & 4.5 & 4.5 & 4.5 \\
\hline Digestbile methionine+cysteine & 9.5 & 8.9 & 8.7 & 8.2 & 8.0 & 7.5 \\
\hline Digestbile lysine & 12.8 & 12.0 & 11.5 & 10.8 & 10.2 & 9.6 \\
\hline Digestible threonine & 8.6 & 8.6 & 7.7 & 7.7 & 6.8 & 6.8 \\
\hline Digestible tryptophan & 2.5 & 2.4 & 2.4 & 2.3 & 2.1 & 1.9 \\
\hline Digestible arginine & 14.4 & 13.2 & 13.7 & 12.9 & 11.8 & 10.9 \\
\hline Digestible leucine & 17.1 & 16.1 & 16.3 & 15.5 & 14.4 & 13.7 \\
\hline Digestible isoleucine & 9.1 & 8.2 & 8.6 & 8.0 & 7.3 & 6.8 \\
\hline Digestible valine & 9.8 & 9.0 & 9.2 & 8.6 & 7.9 & 7.4 \\
\hline Crude fat & 63.7 & 55.1 & 84.8 & 81.3 & 86.9 & 81.8 \\
\hline Crude fibre & 22.9 & 22.3 & 22.3 & 22.4 & 21.7 & 21.4 \\
\hline Crude ash & 34.4 & 32.0 & 32.2 & 29.6 & 27.2 & 25.6 \\
\hline Sodium & 1.6 & 1.6 & 1.6 & 1.6 & 1.6 & 1.6 \\
\hline
\end{tabular}

Vitamin-trace mineral premix/kg diet: vitamin A: $12000 \mathrm{IU}$, vitamin $\mathrm{D}_{3}: 1500 \mathrm{IU}$, vitamin $\mathrm{E}: 50 \mathrm{mg}$, vitamin $\mathrm{K}_{3}: 5 \mathrm{mg}$, vitamin B1: $3 \mathrm{mg}$, vitamin B2: $6 \mathrm{mg}$, vitamin B6: $5 \mathrm{mg}$, vitamin B12: $0.03 \mathrm{mg}$, niacin: $25 \mathrm{mg}$, calcium-d-pantothenate: 12 mg, folic acid: $1 \mathrm{mg}$, D-biotin: $0.05 \mathrm{mg}$, apo-carotenoic acid ester: $2.5 \mathrm{mg}$, choline chloride: $400 \mathrm{mg}$, manganese: $80 \mathrm{mg}$, iron: $60 \mathrm{mg}$, zinc: $60 \mathrm{mg}$, copper: $5 \mathrm{mg}$, cobalt: $0.2 \mathrm{mg}$, iodine: $1 \mathrm{mg}$, selenium: $0.15 \mathrm{mg}$

The enzyme (Ronozyme® Proact, DSM Nutritional Products Ltd, Istanbul, Turkey) that was used in this study was a purified mono component serine protease produced by submerged fermentation of Bacillus licheniformis, which contained transcribed genes from Nocardiopsis prasina. The enzyme activity for this protease is measured in protease units, with 1 unit being defined as the amount of enzyme that releases 1 $\mu \mathrm{mol}$ of $\mathrm{p}$-nitroaniline from $1 \mu \mathrm{M}$ substrate per minute at $\mathrm{pH} 9.0$ and $37^{\circ} \mathrm{C}$. The product, which consisted of 
of 75,000 protease units/g of enzyme, was added according to the manufacturer's recommendation at 200 ppm of protease (15,000 protease units $/ \mathrm{kg})$ (Freitas et al., 2011).

Throughout the experiment, broilers were handled according to the principles for the care of animals in experimentation (Ross 308, 2009). During the 42-day period, their growth performance was evaluated by recording BWG, FI, and FCR. Bodyweight was recorded at the beginning of the experiment then weekly. Feed supplied and left over were recorded weekly. The FI data were adjusted for mortalities. Feed conversion ratio was calculated weekly as a ratio of FI to BWG. Mortality was recorded as it occurred. The effects of treatments on initial and final BWs and BWGs, FIs, and FCR of broilers from hatching to 42 days are shown in Table 3.

At the end of the experiment, 15 broiler chickens from each group whose BWs were similar to the group average were selected, legbanded and weighed after eight-hour fastingThe $\mathrm{m}$. A sodium pentobarbital injection $(100 \mathrm{mg} / \mathrm{kg})$ was applied as anaesthesia before slaughter. A total of 45 chickens were slaughtered by severing the jugular vein to determine the pre-slaughter BW, the relative weight of certain digestive organs, and hot and cold carcass yields. When the broilers were completely immobilized, carcasses were scalded at $55{ }^{\circ} \mathrm{C}$ to $60{ }^{\circ} \mathrm{C}$ for 45 seconds and defeathered in a rotary plucker. The carcasses were immediately plucked, processed (removal of head and feet), eviscerated, weighed and then chilled overnight in a refrigerator $\left(+4{ }^{\circ} \mathrm{C}\right)$. The measurements included hot and cold carcass yields. The weights of the proventriculus, spleen, gizzard, heart, abdominal fat, bursa fabricius, liver, small intestine, and pancreas were measured individually to the nearest $\pm 0.001 \mathrm{~g}$ and values were recorded. These weights were calculated as a percentage of the pre-slaughter BW of the chickens. The carcasses were vacuum packed and stored in a freezer at $-80^{\circ} \mathrm{C}$ until required for analysis of dry matter, crude protein, crude fat and crude ash contents. The carcasses were removed from the freezer, thawed and minced with a chopper. The dry matter, crude protein, crude fat and crude ash contents of meat were determined (AOAC, 2007).

At the end of the experiment (42 days), blood samples from the 45 chickens were collected in test tubes without anticoagulant and centrifuged at $3000 \mathrm{rpm}$ for $15 \mathrm{~min}$. at $+4^{\circ} \mathrm{C}$. After centrifugation, the serum was removed and stored in Eppendorf tubes at $-80^{\circ} \mathrm{C}$ until analysis. Serum samples were analysed with an audit autoanalyser using its test kits for total cholesterol, VLDL cholesterol, triglyceride, total protein, uric acid and $\mathrm{NH}_{3}$ at the biochemistry laboratory of Medicine Faculty of Tokat Gaziosmanpasa University.

Fifty broilers were raised in metabolic cages from 35 days to 42 days old as an adjustment period to determine the ileal digestibility of crude protein. On day $35,0.3 \%$ chromium oxide was added to all diets as an indigestible marker to determine the ileal digestibility of crude protein. On the 42nd day, the chickens were slaughtered and after washing the ileum with bidistile water, one sample pool was formed from the 10 ileum contents of each treatment. As a result, 15 ileum sample pools for three treatment groups were formed. The contents of the ileum (from the Meckels diverticulum to the ileosecal connection) were collected and weighed, lyophilized, milled and sieved through a $0.5 \mathrm{~mm}$ diameter sieve and stored at $-80{ }^{\circ} \mathrm{C}$ until analysis. All diets and ileum samples were analysed in triplicate for crude protein (AOAC, 2007) at Agricultural Faculty, Department of Animal Science Laboratory, Tokat Gaziosmanpasa University. Chromium was analysed with inductively coupled plasma - optical emission spectrometry (ICAP 7000 Series, Waltham, MA USA) (Williams et al., 962). In vitro protein digestibility was calculated as:

$$
\text { Percent digestibility }=100\left(1-\frac{N_{i} \cdot C_{d}}{N_{d} \cdot C_{i}}\right)
$$

Where: $N_{i}$ is the concentration of protein in the contents of the ileum,

$N_{d}$ is the concentration of protein in the diet,

$C_{d}$ is the concentration of chromium in the diet and

$C_{i}$ is the concentration of chromium in the contents of the ileum (Mohammadigheisar \& Kim, 2018).

A linear model (Release 6.1, SPSS Inc., Chicago, Illinios, USA) for one-way analysis of variance was applied to data from the experiment. Significant differences between treatment means were separated using Duncan's multiple range test (Duncan, 1955). Results were presented as least square means and standard error of means. All statements of significance were based on $P<0.05$.

\section{Results and Discussion}

The PC diet increased final BW $(P<0.001)$, BWG $(P<0.001)$ and $\mathrm{FI}(P<0.05)$ and improved the FCR $(P<0.01)$ of broilers compared with the other diets. Moreover, the NC+ENZY diet enhanced final BW $(P$ $<0.001)$, BWG $(P<0.001)$, and FI $(P<0.05)$, and improved FCR $(P<0.01)$ of broilers compared with the NC diet. The effects of the diets on the final BW and BWG, FI and FCR of broilers at $0-6$ weeks are given in Table 2. 
The curent results agree with the findings of Manangi et al. (2009), Rosa et al. (2009) and Fru-Nji et al. (2011), who reported that protease supplementation to a diet with reduced crude protein and digestible amino acid contents at the level of $5 \%$ or $6 \%$ significantly improved the growth performance of broilers compared with the diet without protease supplementation. Similarly, the results for growth performance agree with the findings of Mohammadigheisar and Kim (2018) feeding chickens the LP diet had negative effects on BWG and FCR compared with the PC diet and the LP diet supplemented with protease. In addition, Law et al. (2018) noted that reducing dietary crude CP linearly reduced BWG and reduced the FCR of broilers, while protease supplementation improved their BWG and FCR. The improvements in BWG and FCR of broilers fed the NC+ENZY diet in the current trial might have been derived from the improvement in digestibility for most essential amino acids, which was caused by the supplementation of protease to the diet (Mohammadigheisar \& Kim, 2018). Similarly Angel et al. (2011) reported that protease supplementation at a concentration of $200 \mathrm{ppm}$ to the LP diet improved the BWG and FCR of broilers compared with the PC diet. The NC diet in the current trial decreased FI significantly compared with the other diets $(P<0.05)$. This may be because one or more amino acids are regulating FI rather than CP concentrations per se (Sklan \& Plavnik, 2002; Law et al., 2018)

Table 2 Effects of experimental diets on the final bodyweight, bodyweight gain, food intake, and food convernsion ratio of broilers from 0 to 6 weeks

\begin{tabular}{lccccc}
\hline \multicolumn{1}{c}{ Diet } & $\begin{array}{c}\text { Initial } \\
\text { bodyweight, } g\end{array}$ & $\begin{array}{c}\text { Final } \\
\text { bodyweight, }\end{array}$ & Gain, g & Feed intake, g & $\begin{array}{c}\text { Feed } \\
\text { Conversion } \\
\text { ratio }\end{array}$ \\
\hline Positive control & 41.85 & $2279.28^{\mathrm{a}}$ & $2237.43^{\mathrm{a}}$ & $3821.46^{\mathrm{a}}$ & $1.710^{\mathrm{a}}$ \\
Negative control $_{\text {Negative control with protease }}{ }^{\mathrm{a}}$ & 41.85 & $1951.78^{\mathrm{C}}$ & $1909.93^{\mathrm{c}}$ & $3672.35^{\mathrm{c}}$ & $1.927^{\mathrm{C}}$ \\
SE & 41.84 & $2040.37^{\mathrm{b}}$ & $1998.53^{\mathrm{b}}$ & $3777.30^{\mathrm{b}}$ & $1.891^{\mathrm{b}}$ \\
$P$-value & 0.02 & 43.43 & 43.44 & 26.73 & 0.03 \\
& 0.99 & $<0.01$ & $<0.01$ & 0.04 & $<0.01$
\end{tabular}

$\overline{\mathrm{a}, \mathrm{b}, \mathrm{c}}$ Within a column, means with a common superscipt did not differ at $P=0.05$

${ }^{1}$ protease supplemented at $200 \mathrm{mg} / \mathrm{kg}$

The PC diet increased the uric acid $(P<0.01)$, total protein $(P<0.05)$, total cholesterol $(P<0.05)$, triglyceride $(P<0.05)$, and VLDL cholesterol contents $(P<0.05)$ and reduced the $\mathrm{NH}_{3}$ content $(P<0.01)$ of serum compared with the other diets.

The NC diet $(P<0.05)$ decreased the serum total protein and uric acid $(P<0.01)$ levels, and increased the serum triglyceride level compared with the NC+ENZY diet $(P<0.05)$. These results agree with those of Law et al. (2018), who reported that reducing the crude protein level decreased serum total protein and uric acid significantly, and increased the serum triglyceride level. The decrease in uric acid could be associated with a deficiency in digested and consumed amino acids owing to the LP diet because uric acid is a byproduct of protein catabolism (Law et al., 2018). The effects of the diets on the serum biochemistry parameters of broilers are summarized in Table 3.

In the curent study, protease supplementation to a diet with low crude protein affected the serum uric acid level of broilers similarly to of broilers fed an LP diet. This finding did not concur with the results of Law et al. (2018), who reported that an LP diet supplemented with protease decreased the serum uric acid level of broilers significantly compared with the crude protein diet without protease.

The effects of the experimental diets on the relative weights of internal organs and carcass yields of broilers are given in Table 4.

The PC diet decreased the relative weights of the proventriculus $(P<0.01)$, gizzard $(P<0.01)$, and abdominal fat $(P<0.05)$, and increased the relative weight of the liver $(P<0.05)$ of broilers compared with the other diets (Table 5). The NC+ENZY diet did not influence the relative weight of the livers of broilers significantly compared with the NC diet. This finding agrees with the results of Ndazigaruye et al. (2019), who reported that protease supplementation to the LP diet did not significantly affect the relative weight of the livers of broilers compared with the unsupplemented LP diet. Moreover, the treatments did not affect the relative weight of the pancreas. This result concurs with the findings of Ndazigaruye et al. (2019), who reported that neither CP nor protease enzyme influenced the relative weight of the pancreas of broilers at 35 days. In addition, in the current study, the NC diet increased the relative weight of abdominal fat significantly 
compared with the other diets $(P<0.05)$. This situation may be derived from a higher calorie to protein ratio in low protein diets because excess energy is diverted to abdominal fat deposition (Law et al., 2018). The current result for the relative weight of abdominal fat concurs with the findings of Law et al. (2018), who reported that the rate of abdominal fat deposition was significantly higher in birds fed the LP diet compared with the LP diet supplemented with protease. These findings do not agree with Freitas et al. (2011), who pointed out that the diet with normal protein did not influence the abdominal fat weight of broilers significantly compared with the diet with reduced crude protein at the level of $4.4 \%$ and an LP diet supplemented with protease at $200 \mathrm{ppm}$.

Table 3 Effects of experimental diets on the serum biochemistry parameters of broilers

\begin{tabular}{lccccc}
\hline Serum constituents & Positive control & Negative control & $\begin{array}{c}\text { Negative control } \\
\text { with protease }\end{array}$ & SE & $P$-value \\
\hline Uric acid, $\mathrm{mg} / \mathrm{dl}$ & $2.800^{\mathrm{a}}$ & $2.614^{\mathrm{b}}$ & $2.629^{\mathrm{b}}$ & 0.129 & 0.008 \\
Total protein, g/l & $3.220^{\mathrm{a}}$ & $2.864^{\mathrm{b}}$ & $2.993^{\mathrm{b}}$ & 0.070 & 0.011 \\
Total cholesterol, $\mathrm{mg} / \mathrm{dl}$ & $167.867^{\mathrm{a}}$ & $151.643^{\mathrm{b}}$ & $152.267^{\mathrm{b}}$ & 4.248 & 0.021 \\
Triglyceride, $\mathrm{mg} / \mathrm{dl}$ & $49.933^{\mathrm{a}}$ & $41.214^{\mathrm{b}}$ & $37.067^{\mathrm{C}}$ & 3.243 & 0.025 \\
VLDL cholesterol, $\mathrm{mg} / \mathrm{dl}$ & $10.533^{\mathrm{a}}$ & $8.214^{\mathrm{b}}$ & $7.400^{\mathrm{c}}$ & 0.669 & 0.013 \\
Ammonia, $\mu \mathrm{mol} / \mathrm{L}$ & $346.787^{\mathrm{c}}$ & $377.693^{\mathrm{a}}$ & $356.593^{\mathrm{b}}$ & 16.893 & 0.008
\end{tabular}

$\overline{a, b, c}$ Within a row, means with a common superscipt did not differ at $P=0.05$

${ }^{1}$ protease supplemented at $200 \mathrm{mg} / \mathrm{kg}$; VLDL: very low density lipoprotein

Table 4 Effects of experimental diets on the relative weights of internal organs and carcass yields of broilers

\begin{tabular}{|c|c|c|c|c|c|}
\hline Organ, \% & $\begin{array}{l}\text { Positive } \\
\text { control }\end{array}$ & Negative control & $\begin{array}{l}\text { Negative } \\
\text { control with } \\
\text { protease }\end{array}$ & SE & $P$-value \\
\hline Proventiculus & $0.373^{\mathrm{C}}$ & $0.446^{\mathrm{a}}$ & $0.413^{b}$ & 0.009 & 0.002 \\
\hline Spleen & 0.097 & 0.109 & 0.115 & 0.006 & 0.448 \\
\hline Gizzard & $2.085^{\mathrm{b}}$ & $2.571^{\mathrm{a}}$ & $2.555^{\mathrm{a}}$ & 0.059 & 0.002 \\
\hline Heart & 0.457 & 0.474 & 0.467 & 0.009 & 0.751 \\
\hline Bursa fabricius & 0.242 & 0.252 & 0.236 & 0.009 & 0.747 \\
\hline Liver & $2.310^{\mathrm{a}}$ & $2.070^{\mathrm{b}}$ & $2.071^{b}$ & 0.064 & 0.021 \\
\hline Small intestine & 3.654 & 3.641 & 3.629 & 0.112 & 0.996 \\
\hline Pancreas & 0.193 & 0.204 & 0.201 & 0.007 & 0.794 \\
\hline \multicolumn{6}{|l|}{ Carcass, } \\
\hline Abdominal fat & $1.835^{\mathrm{C}}$ & $2.296^{a}$ & $1.905^{\mathrm{b}}$ & 0.077 & 0.026 \\
\hline Hot yield & $72.019^{a}$ & $70.127^{\mathrm{C}}$ & $71.215^{\mathrm{b}}$ & 0.263 & 0.010 \\
\hline Cold yield & $71.674^{\mathrm{a}}$ & $69.633^{\mathrm{C}}$ & $70.714^{\mathrm{b}}$ & 0.262 & 0.004 \\
\hline
\end{tabular}

The PC diet increased hot $(P<0.05)$ and cold $(P<0.01)$ carcass yields compared with the other diets. Also, the NC+ENZY diet enhanced hot $(P<0.05)$ and cold $(P<0.01)$ carcass yields of broilers significantly compared with the NC diet. The results for the carcass yield of broilers agree with the findings of Law et al. (2018), who reported that carcass yield was decreased when the broilers were fed the LP diet. There are conflicting reports on the effect of protease supplementation on the carcass yield of broilers. Abudabos (2012) noticed an increase in carcass yield, whereas Rehman et al. (2017) pointed out that there was no significant effect on carcass yield The improvement in hot and cold carcass yields because of protease 
supplementation is associated with the increased utilization and deposition of protein compared with the LP diet (Lauri et al., 2003; Law et al., 2018).

Treatment effects on ileal protein digestibility were highly significant $(P<0.001)$. Broilers fed the PC diet had higher ileal digestibility of crude protein at 42 days of age $(83.6 \pm 0.7 \%)$ than the birds that were fed the NC diet $(78.6 \pm 0.7 \%)$. Likewise, ileal protein digestibility by the birds fed the NC+ENZY diet $(82.6 \pm$ $0.7 \%$ ) was higher in comparison to those fed the NC diet. Supplementation of protease to the LP diet influenced the digestibility of crude protein positively (Borda-Molina et al., 2019). This positive effect might have derived from the ability to target protease inhibitors and the cereal portion of the diet (Liu et al., 2013; Mohammadigheisar \& Kim, 2018).

The current findings for ileal CP digestibility concur with those of Mahmood et al. (2017), who noted that $\S$ the diet supplemented with protease improved apparent total tract digestibility for nitrogen significantly. However, this finding did not concur with the results of Angel et al. (2011) and Freitas et al. (2011), who reported that protease supplementation to an LP diet improved the ileal digestibility of crude protein significantly compared with that of broilers fed a diet with normal crude protein. Mohammadigheisar \& Kim (2018) also reported that protease supplementation to the LP diet did not affect the CP digestibility significantly compared with the normal and low CP diets.

The PC diet increased the dry matter $(P<0.05)$, crude protein $(P<0.001)$ and crude ash $(P<0.01)$ contents of the meat (Table 5). However, it decreased the crude fat content of meat $(P<0.01)$ compared with the NC diet. The NC+ENZY diet increased the crude protein content of the meat significantly compared with he NC diet $(P<0.001)$. Similarly the PC diet influenced the dry matter, crude protein and crude fat contents of meat compared with the NC+ENZY diet. The improvement in meat protein content with protease supplementation might have been derived from the increased utilization and deposition of protein (Lauri et al., 2003; Law et al., 2018).

Table 5 Effects of experimental diets on the proximate analysis of meat from broilers

\begin{tabular}{lccccc}
\hline Variable & Positive control & Negative control & $\begin{array}{c}\text { Negative control with } \\
\text { protease }\end{array}$ & SE & $P$-value \\
\hline Dry matter, \% & $25.23^{\mathrm{a}}$ & $25.03^{\mathrm{b}}$ & $25.11^{\mathrm{ab}}$ & 0.036 & 0.048 \\
Crude protein, \% & $21.42^{\mathrm{a}}$ & $20.34^{\mathrm{b}}$ & $21.25^{\mathrm{a}}$ & 0.152 & 0.000 \\
Crude fat, \% & $3.01^{\mathrm{b}}$ & $3.10^{\mathrm{a}}$ & $3.02^{\mathrm{b}}$ & 0.016 & 0.009 \\
Crude ash, \% & $0.93^{\mathrm{a}}$ & $0.84^{\mathrm{b}}$ & $0.89^{\mathrm{b}}$ & 0.013 & 0.008 \\
\end{tabular}

${ }^{a, b}$ Within a row, means with a common superscipt did not differ at $P=0.05$

${ }^{1}$ protease supplemented at $200 \mathrm{mg} / \mathrm{kg}$;

\section{Conclusion}

Protease supplementation at the level of $200 \mathrm{mg} / \mathrm{kg}$ may not remove the detrimental effects caused by a $6 \%$ reduction in crude protein and digestible amino acids on growth performance, hot and cold carcass yields and ileal digestibility of crude protein in broilers.

\section{Acknowledgments}

This work was supported financially completely by Fundamental Research Funds for Tokat Gaziosmanpasa University (grant number. 2015/120).

\section{Authors' Contributions}

The authors developed the original hypotheses, designed the experiments, collected the data, conducted the statistical analyses, collaborated in interpeting the results, wrote the initial draft and finalized the manuscript. All authors have read and approved the finalized manuscript.

\section{Conflict of Interest Declaration}

There is no conflict of interest.

\section{References}

Abudabos, A.M. 2012. Effect of enzyme supplementation to normal and low density broiler diets based on corn-soybean meal. Asian J. Anim. Vet. Adv. 7, 139-148.

Angel, C.R., Saylor, W., Vieira, S.L. \& Ward, N., 2011. Effects of a mono-component protease on performance and protein utilization in 7 to 22 day old broiler chickens. Poult. Sci. 90, 2281-2286. 
AOAC (Association of Official Analytical Chemists), 2007. Official methods of analysis (18th ed.). Washington, DC, USA.

Berda-Molina, D., Zuber, T., Siegert, W., Camarinha-Silva, A., Feverstein, D. \& Rodehutscard, M., 2019. Effects of protease and phytase supplements on small intestinal microbiota and amino acid digestibility in broiler chickens. Poult. Sci. 98, 2906-2918.

Dessimoni, G.V., Dalolio, F.S., Moreira, J., Teixeira, L.V., Bertechini, A.G. \& Hermes, R.G., 2019. Protease supplementation under amino acid reduction in diets formulated with different nutritional requirements for broilers. Brazilian J. Poult. Sci. 21 (1), 1-8.

Dosković, V., Bogosavljević-Bošković, S., Pavlovski, Z., Milošević, B., Škrbic, Z., Radonjac, S. \& Petričević, V., 2013. Enzymes in broiler diets with special reference to protease. World's Poult. Sci. Assoc. 69, 343-359.

Duncan, D.B., 1955. Multiple range test and multiple F tests, Biometrics 11, 1-42.

Du Plessis, R.E. \& Van Rensburg, C.J., 2014. Carbohydrase and protease supplementation increased performance of broilers fed maize-soybean-based diets with restricted metabolisable energy content. S. Afr. J. Anim. Sci. 44, 262270.

Favero, A., Maiorka, A., Rocha, C., Appelt, M.D. \& Sorbara, J.O.B., 2009. Effect of protease enzyme on performance and ileal digestibility of broilers grown to 42 days of age in floor pen. Int. Poult. Scientific Forum. Atlanta, Georgia. Abstracts of papers M28, pp. 9.

Fidelis, F., Kluenter, A., Fisher, M. \& Pontoppidan, K., 2010. A feed serine protease improves broiler performance and increases protein and energy digestibility. J. Poult. Sci. 48 (4), 239-246.

Freitas, D.M., Vieira, S.L., Angel, C.R., Favero, A. \& Maiorka, A., 2011. Performance and nutrient utilization of broilers fed diets supplemented with a novel mono-component protease. J. Appl. Poult. Res. 20, 322-334.

Fru-Nji, F., Kluenter, A.M., Fischer, M. \& Pontoppidan, K., 2011. A feed serin protease improves broiler performance and increases protein and energy digestibility. J. Poult. Sci. 48, 239-246.

Lauri, A., Hanauska, B., Alfred, M. \& Duftly, J.R., 2003. Blood chemistry, cytology and body condition in adult northern gashawks. J. of Raptor Res. 37, 299-306.

Law, F.L., Zulkifli, I., Soleimani, A.F., Liang, J.B. \& Awad, E.A., 2018. The effect of low-protein diets and protease supplementation on broilers chickens in a hot and humid tropical environment. Asian-Austral. J. Anim. Sci. 31, 1291-1300.

Liu, S.Y., Sell, P.H., Court, S.G. \& Cowieson, A.J., 2013. Protease supplementation of sorghum-based diets enhances amino acid digestibility coefficients in four small intestinal sites and accelerates their rates of digestion. Anim. Feed Sci. Technol. 183, 175-183.

Mahmood, T., Mirza, M.A., Nawaz, H. \& Shahid, M., 2017. Effect of different exogenous proteases on growth performance, nutrient digestibility and carcass response in broiler chickens fed poultry by-product meal-based diets. Livest. Sci. 200, 71-75.

Manangi, M. K., Wehmeyer, M. E., Garlich, J. D., Odetallah, N. \& Vazquez-Anon, M., 2009. The effect of a protease on performance of broilers fed corn-soybean meal diets containing different levels of crude proteinand amino acids. 2009 Poultry Science Association Annual Meeting Abstracts. Poult. Sci. 88 (Suppl. 1), 70.

Mohammadigheiser, M. \& Kim, I.H., 2018. Addition of a protease to low crude protein density diets of broiler chickens. J. Appl. Anim. Res. 46, 1377-1381.

Ndazigaruye, G., Kim, D.H., Kang, C.W., Joo, Y.J., Lee, S.R. \& Lee, K.W., 2019. Effects of low-protein diets and exogenous protease on growth performance, carcass traits, intestinal morphology, cecal volatile fatty acids and serum parameters in broilers. Anim. 9 (226), 2-16.

Rada, V., Lichovnikova, M. \& Foltyn, M., 2014. The effect of serine protease on broiler growth and carcass quality. Acta Fytotch. Zootechn. 17 (3), 87-89.

Rehmani, Z., Kamran, J., Abd El-Hack, M.E., Alagawany, M., Bhatti, S.A., Ahmad, G., Saleem, A., Ullah, Z., Yameen, R.M.K. \& Ding, C., 2017. Influence of low-protein and low amino acid diets with different sources of protease on performance, carcasses and nitrogen retention of broiler chickens. Anim. Prod. Sci. 58(9), 1625-1631.

Rosa, A.P., Scher, A., Stefanello, C., Diaz, E., Dvarte, V., Oichenaz, N. \& Sorbara, J.O.B., 2009. Effect of pure protease enzyme and dietary protein/amino acid levels on broiler performance. Int. Poult. Scientific Forum. Georgia World Congress Center, Atlanta, Georgia. 26-27January 2009. Pp. 33.

Ross Broiler Management Manual 2009. Aviagen. http://www.thepoultrysite.com/downloads/single/94/

Sklan, D. \& Plavnik, I. 2002. Interactions between dietary crude protein and essential amino acid intake on performance in broilers. Br. Poult. Sci. 43, 442-449.

Williams, C.H., David, D.J. \& lismaa, O., 1962. The determination of chromic oxide in faeces samples by atomic absorption spectrophotometry. J. Agric. Sci. 59, 381-385.

WPSA. 1989. European table of energy values for poultry feedstuffs. (3rd ed.). WPSA Subcommittee, Beekbergen, The Netherlands. 